\title{
TAHAP KEPUASAN IBU BAPA TERHADAP KUALITI PENDIDIKAN PRASEKOLAH DI DAERAH MARAN, PAHANG
}

\author{
The Level of Parental Satisfaction Towards the Quality of Preschool Education in Maran \\ District, Pahang
}

Tham Hou Yin

Fakulti Pendidikan dan Pembangunan Manusia, Universiti Pendidikan Sultan Idris

35900 Tanjung Malim, Perak, Malaysia

fionetham@outlook.com

\begin{abstract}
ABSTRAK
Kajian ini dijalankan untuk mengenal pasti tahap kepuasan ibu bapa terhadap kualiti pendidikan prasekolah di daerah Maran, Pahang. Kajian ini juga menentukan perbezaan di antara tahap kepuasan ibu bapa terhadap kualiti pendidikan prasekolah dengan berdasarkan faktor jenis prasekolah, jantina, tahap pendidikan dan pendapatan. Teori Expectancy-Disconfirmation telah digunakan sebagai teori asas kajian ini. Ia disokong oleh model Harris Interactive Poll Organization. Pendekatan kuantitatif dengan reka bentuk kajian tinjauan deskriptif digunakan dalam kajian ini. Pemilihan subjek kajian dijalankan secara persampelan rawak berlapis melibatkan 148 orang ibu bapa, di mana 74 orang ibu bapa dipilih dari tiga buah prasekolah KPM dan 74 orang ibu bapa dipilih dari tiga buah prasekolah swasta di daerah Maran. Daripada 74 orang ibu bapa dari prasekolah KPM dan prasekolah swasta masing-masing, 37 orang ibu dan 37 orang bapa dipilih sebagai sampel secara rawak. Data dikumpul menggunakan soal selidik skala Likert empat mata. Sebelum pengumpulan data, instrumen diuji di sebuah prasekolah KPM dan sebuah prasekolah swasta di daerah Maran untuk memastikan kesahan dan kebolehpercayaan. Data yang dikumpul dianalisis dengan menggunakan perisian Statistical Package for the Social Science (SPSS) versi 23.0. Data dianalisis dengan menggunakan analisis deskriptif dan inferensi. Analisis deskriptif menjelaskan tahap kepuasan ibu bapa terhadap kualiti pendidikan prasekolah, manakala analisis inferensi melibatkan ujian t sampel bebas dan ujian Anova sehala yang menerangkan perbezaan antara tahap kepuasan ibu bapa terhadap kualiti pendidikan prasekolah dengan faktor demografi. Dapatan kajian menunjukkan bahawa tahap kepuasan ibu bapa terhadap kualiti pendidikan prasekolah adalah tinggi. Ujian $\mathrm{t}$ sampel bebas menunjukkan terdapat perbezaan signifikan di antara tahap kepuasan ibu bapa dengan jenis prasekolah tetapi tidak terdapat perbezaan signifikan di antara tahap kepuasan ibu bapa dengan faktor jantina. Analisis Anova sehala pula menunjukkan tidak terdapat perbezaan signifikan di antara tahap kepuasan ibu bapa dengan tahap pendidikan dan pendapatan ibu bapa. Kesimpulan daripada kajian menunjukkan bahawa ibu bapa sangat berpuas hati dengan kualiti pendidikan prasekolah yang diberikan kepada anak-anak mereka di daerah Maran, Pahang dengan skor min keseluruhan 3.23. Kajian ini mencadangkan agar kerajaan dan pihak berkepentingan mengambil langkah untuk meningkatkan lagi kualiti pendidikan prasekolah dan memperuntukkan sumber untuk memenuhi tuntutan ibu bapa.
\end{abstract}

Kata Kunci: Pendidikan prasekolah, kualiti, kepuasan ibu bapa

\begin{abstract}
The present study was conducted to identify the level of parental satisfaction towards the quality of preschool education in Maran district, Pahang. This study also determines the significance difference between the level of parental satisfaction towards the quality of preschool education based on the factors of type of preschool, gender, education and income. The Expectancy-Disconformation Theory was used as the basic theory of the study. It was supported by the model of Harris Interactive Poll Organization. The quantitative approach with descriptive survey design was used in this study. The selection of sample was conducted by a stratified random sampling technique that involving 148 parents, in which 74 parents were selected from three KPM preschool and 74 parents were selected from three private preschool in Maran district. Of the 74 parents from KPM preschool and private preschool respectively, 37 mothers and 37 fathers were randomly selected. Data was collected using a four point Likert scale questionnaire. Prior to data collection, the instrument was pilot-tested in a KPM preschool and a
\end{abstract}


private preschool in Maran district to ensure validity and reliability. Statistical Package for Social Science (SPSS) version 23.0 was used during data analysis. Descriptive and inferential statistics were computed. Descriptive statistics describes the level of parental satisfaction towards the quality of preschool education, while inferential statistics that involves independent samples t-test and One-way Analysis of Variance (ANOVA) describes the diffenrence between the level of parental satisfaction towards the quality of preschool education based on the demographic factors. The results showed that the level of parental satisfaction towards the quality of preschool education was high. The independent samples $t$-test showed that there was a significant difference between the level of parental satisfaction by the type of preschool but there was no significant difference between the level of parental satisfaction by parents' gender. One-way Analysis of Variance (Anova) showed that there was no significant difference between the level of parental satisfaction by parents' education level and income. Conclusion from the study showed that parents were very satisfied towards the quality of preschool education that given to their children in Maran district, Pahang with a total mean score of 3.23. The study recommended that the governments and stakeholders should find alternative ways to improve the quality of preschool education and allocate resources to meet parents' demands.

Keywords: Preschool education, quality, parental satisfaction

\section{PENGENALAN}

Pendidikan prasekolah merupakan pendidikan asas bagi kanak-kanak sebelum memasuki alam persekolahan di peringkat sekolah rendah. Menurut Al Shatti (2011), prasekolah merupakan tempat di mana kanak-kanak menerima pendidikan formal pertama dan didedahkan kepada pengetahuan, dan ia adalah satu peralihan pendidikan dari rumah ke sekolah.

Menurut Halim (1989, dalam Norsalmiah Muhammad, 2009), kajian-kajian di negara-negara maju didapati bahawa mempunyai kesan positif terhadap perkembangan kognitif dan afektif kanakkanak bagi mereka yang mengikuti pendidikan prasekolah. Sementara itu, dari kajian yang dijalankan oleh Kementerian Pendidikan Malaysia dengan kerjasama UNICEF (United Nations International Children's Emergency Fund) (1980-1984) didapati bahawa kanak-kanak yang mempunyai pengalaman pendidikan prasekolah lebih bersedia untuk mengikuti pendidikan formal di sekolah rendah (Norhamiza Ismail, 2009).

Sebagaimana yang dinyatakan dari kajian-kajian itu telah menunjukkan betapa pentingnya pendidikan prasekolah sebagai asas kesinambungan pendidikan sekolah rendah dalam menyuburkan potensi kanak-kanak dalam semua aspek pertumbuhan dan perkembangan diri yang seimbang dan sempurna. Kanak-kanak itu dikhuatiri akan menghadapi masalah keciciran pelajaran berbanding pelajar lain sekali gus merugikan mereka bagi mencapai tahap kecemerlangan pelajaran sekiranya tidak dihantar untuk menerima pendidikan prasekolah yang sedia ada di negara ini.

Pendidikan prasekolah merupakan waktu yang baik bagi membentuk dan memupuk perkembangan kecerdasan serta potensi kanak-kanak. Hal ini disebabkan kanak-kanak mempunyai waktu tertentu yang sangat singkat dan perlu mendapat perhatian serius iaitu waktu kritikal. Pernyataan ini turut disokong oleh Norsalmiah Muhammad (2009) di mana beliau menyatakan bahawa sempurna atau tidaknya asuhan yang diperolehi oleh kanak-kanak amat mempengaruhi perkembangan intelek, emosi dan jasmani kanak-kanak terutama sekali dalam waktu kritikal.

Menyedari akan kepentingan pendidikan prasekolah merupakan waktu yang baik bagi memupuk perkembangan diri kanak-kanak, maka pendidikan kanak-kanak turut mendapat perhatian daripada para ibu bapa. Kenyataan ini disokong oleh Shabnam (2003) yang menyatakan bahawa ibu bapa melihat pendidikan prasekolah memainkan peranan penting kerana ia membantu kanak-kanak berjaya dalam melengkapkan pendidikan rendah. Kanak-kanak yang menerima pendidikan prasekolah yang berkualiti dikatakan lebih cenderung untuk mencapai kejayaan di sekolah mahupun dalam kehidupan (Sander, 2003). 
Sebagai ibu bapa, mereka mempunyai kuasa untuk terlibat secara aktif di dalam pengalaman prasekolah anak mereka. Ibu bapa perlu membuat satu keputusan yang besar apabila anak-anak mereka mencapai usia yang sepatutnya untuk menerima pendidikan formal dan pada masa itulah ibu bapa perlu memilih pengalaman pendidikan formal pertama kepada anak mereka. Menurut Goldring \& Rowley (2006), salah satu perkara yang penting di mana ibu bapa melibatkan diri dalam pendidikan anak-anak mereka adalah melalui pemilihan sekolah yang anak mereka hadiri. Tidak dapat dinafikan, semua ibu bapa ingin memberikan segala yang terbaik untuk anak-anak mereka, termasuk prasekolah. Menyedari akan kepentingan pendidikan prasekolah ini, maka para ibu bapa turut menghantar anak mereka ke prasekolah untuk menerima pendidikan.

Kewujudan prasekolah di Malaysia ini menjadi suatu realiti yang tidak dapat diketepikan. Memandangkan pelbagai buah prasekolah tumbuh seperti cendawan selepas hujan, tambahan pula permintaan yang tinggi dalam kalangan ibu bapa terhadap pendidikan prasekolah pada zaman sekarang, maka wujudlah pemilihan ibu bapa apabila membuat keputusan mengenai prasekolah bagi anak mereka dari aspek kurikulum, kualiti guru, kemudahan dan kelengkapan, sumber kewangan serta lokasi tempat. Pertumbuhan prasekolah di Malaysia yang berlaku secara meningkat secara tidak langsungnya memberi peluang kepada para ibu bapa dalam membuat pertimbangan yang sewajarnya dengan memilih prasekolah yang terbaik untuk anak-anak mereka.

\section{PERNYATAAN MASALAH}

Sejak beberapa tahun kebelakangan ini, permintaan terhadap pendidikan prasekolah telah meningkat. Ibu bapa telah menghantar anak-anak mereka ke pelbagai prasekolah dengan pelbagai kualiti yang ditawarkan dari segi kualiti guru, sikap guru, kemudahan dan kelengkapan serta persekitaran. Dengan menyedari peningkatan permintaan dan kepentingan pendidikan prasekolah yang berkualiti, penyelidik mahupun profesional telah membangunkan suatu piawaian mengenai kualiti pendidikan prasekolah. Walau bagaimanapun, pandangan ibu bapa yang menjadi pemegang kepentingan utama dalam pendidikan prasekolah anak-anak mereka tidak pernah didengar dalam proses ini. Ini telah menimbulkan persoalan tentang bagaimana ibu bapa melihat kualiti pendidikan prasekolah dan sama ada mereka berpuas hati dengan kualiti pendidikan prasekolah atau tidak.

Kajian oleh Omondi (2013) menunjukkan bahawa pengukuran tahap kepuasan ibu bapa terhadap kualiti pendidikan prasekolah harus dilakukan dengan menilai pandangan ibu bapa mengenai beberapa ciri-ciri kualiti pendidikan. Ia termasuklah penyediaan kemudahan fizikal, bahan pengajaran dan pembelajaran, kualiti guru, keselamatan, pemakanan dan pencapaian kanak-kanak (Silva, 2006; Britner \& Phillips, 1995 \& Hoon, 1994). Walau bagaimanapun, kajian seperti ini jarang dilakukan untuk meneroka tahap kepuasan ibu bapa terhadap kualiti pendidikan prasekolah yang diberikan kepada anakanak mereka.

Satu kajian yang dijalankan oleh Mbise (2008) mengenai kualiti pendidikan prasekolah, menunjukkan bahawa kualiti pendidikan prasekolah adalah tidak selaras dengan peningkatan permintaan keperluan pendidikan prasekolah. Walau bagaimanapun, ibu bapa masih menghantar anakanak mereka di prasekolah tersebut. Dengan ini wujudlah lagi persoalan sama ada ibu bapa berpuas hati dengan kualiti pendidikan prasekolah. Begitu juga dengan kajian yang dijalankan oleh Norhamiza Ismail (2009), lebih ramai ibu bapa terus mendaftarkan anak-anak mereka di prasekolah swasta berbanding dengan prasekolah kerajaan. Mereka beranggapan bahawa prasekolah swasta boleh memberikan kualiti pendidikan yang sempurna kepada anak-anak mereka. Walaupun trend seperti ini berlaku, kajian yang terhad telah dilakukan di kawasan daerah Maran, Pahang ini untuk mengetahui tahap kepuasan ibu bapa terhadap kualiti pendidikan prasekolah kerajaan dan swasta.

Kajian juga menunjukkan bahawa pandangan ibu bapa mungkin dipengaruhi oleh ciri demografi, pengalaman dan persekitaran (Da Silva \& Wise, 2006). Beliau berhujah bahawa tahap kepuasan ibu bapa terhadap kualiti pendidikan prasekolah juga dipengaruhi oleh faktor-faktor lain 
seperti jenis sekolah, jantina, pendapatan dan tahap pendidikan. Tetapi, kajian yang terhad dilakukan di kawasan daerah Maran, Pahang untuk melihat bagaimana tahap kepuasan ibu bapa terhadap kualiti pendidikan prasekolah berkaitan dengan faktor-faktor ini. Oleh itu, kajian ini bertujuan untuk memberi tumpuan kepada Daerah Maran, Pahang dan mengkaji sejauhmana tahap kepuasan ibu bapa terhadap kualiti pendidikan prasekolah. Ia juga bertujuan untuk meneroka bagaimana pelbagai faktor mempengaruhi tahap kepuasan ibu bapa terhadap kualiti pendidikan prasekolah yang diberikan kepada anak-anak mereka.

\section{OBJEKTIF KAJIAN}

Dalam melaksanakan kajian ini, pengkaji mengenalpasti beberapa objektif yang perlu dicapai iaitu:

1) Mengenalpasti tahap kepuasan ibu bapa terhadap kualiti pendidikan prasekolah.

2) Mengenalpasti perbezaan di antara tahap kepuasan ibu bapa terhadap kualiti pendidikan prasekolah kerajaan dan swasta.

3) Mengenalpasti perbezaan di antara tahap kepuasan ibu bapa terhadap kualiti pendidikan prasekolah dengan faktor jantina.

4) Mengenalpasti perbezaan di antara tahap kepuasan ibu bapa terhadap kualiti pendidikan prasekolah dengan faktor tahap pendidikan.

5) Mengenalpasti perbezaan di antara tahap kepuasan ibu bapa terhadap kualiti pendidikan prasekolah dengan faktor pendapatan.

\section{PERSOALAN KAJIAN}

Berdasarkan objektif kajian di atas, beberapa persoalan kajian telah dikemukakan seperti berikut:

1) Apakah tahap kepuasan ibu bapa terhadap kualiti pendidikan prasekolah?

2) Adakah terdapat perbezaan di antara tahap kepuasan ibu bapa terhadap kualiti pendidikan prasekolah kerajaan dan swasta?

3) Adakah terdapat perbezaan di antara tahap kepuasan ibu bapa terhadap kualiti pendidikan prasekolah mengikut faktor jantina?

4) Adakah terdapat perbezaan di antara tahap kepuasan ibu bapa terhadap kualiti pendidikan prasekolah mengikut faktor tahap pendidikan?

5) Adakah terdapat perbezaan di antara tahap kepuasan ibu bapa terhadap kualiti pendidikan prasekolah mengikut faktor pendapatan?

\section{METODOLOGI KAJIAN}

Menurut Chua (2014), kajian tinjauan merupakan salah satu kaedah penyelidikan bukan eksperimental yang paling popular yang digunakan dalam pelbagai bidang terutamanya dalam bidang sains sosial. Kajian tinjauan biasa digunakan untuk mendapat pandangan orang ramai mengenai sesuatu isu semasa.

Kajian ini telah menggunakan reka bentuk kajian tinjauan deskriptif untuk mengkaji tahap kepuasan ibu bapa terhadap kualiti pendidikan prasekolah. Kajian tinjauan ini menggunakan kaedah kuantitatif kerana ia sesuai digunakan untuk mendapatkan maklumat yang banyak dalam masa yang singkat. Kajian menggunakan reka bentuk ini untuk mengumpul maklumat daripada sekumpulan besar ibu bapa yang anak-anaknya mendaftar di prasekolah berlesen di daerah Maran. Reka bentuk kajian ini juga digunakan untuk meneroka bagaimana tahap kepuasan ibu bapa terhadap kualiti pendidikan prasekolah berbeza dengan jantina ibu bapa, tahap pendidikan, pendapatan dan jenis prasekolah. Rasional untuk memilih reka bentuk ini adalah berdasarkan keupayaan untuk menyediakan pengkaji dengan teknik yang sesuai untuk mengumpul data secara sistematik daripada sekumpulan besar sampel dengan menggunakan soal selidik sebagai instrumen kajian bagi menjawab persoalan kajian yang berkaitan dengan tahap kepuasan ibu bapa terhadap kualiti pendidikan prasekolah. 
Populasi ialah kumpulan sasaran pengkaji supaya sesuatu dapatan kajian dapat diaplikasikan (Fraenkel \& Wallen, 2009). Dalam kajian ini, populasi sasaran pengkaji terdiri daripada ibu bapa yang anak-anaknya berumur 5 hingga 6 tahun yang mendaftar di prasekolah KPM di bawah kerajaan dan prasekolah swasta di daerah Maran, Pahang. KPM (2017) menunjukkan bahawa terdapat sejumlah 56 prasekolah berdaftar dengan 52 buah prasekolah KPM di bawah kerajaan dan 4 buah prasekolah swasta di daerah Maran.

Menurut Portney \& Walkin (1993, dalam Zanzali \& Hamid, 2010), sampel adalah subset populasi yang dipilih untuk dikaji. Kajian ini telah menggunakan kaedah persampelan rawak berlapis dalam memilih sampel bagi mengurangkan ralat persampelan. Tiga buah prasekolah KPM dan tiga buah prasekolah swasta telah dipilih. Kaedah persampelan ini digunakan kerana kajian ini berminat untuk mengetahui perbezaan tahap kepuasan ibu bapa terhadap kualiti pendidikan prasekolah antara prasekolah kerajaan dan prasekolah swasta. Saiz populasi adalah seramai 244 orang ibu bapa dengan 75 orang ibu bapa dari prasekolah KPM dan 169 orang ibu bapa dari prasekolah swasta. Menurut Krejcie dan Morgan (1970), saiz sampel yang diperlukan bagi bilangan ibu bapa seramai 244 orang ialah 148 orang, dimana 74 orang ibu bapa dipilih dari prasekolah KPM dan 74 orang ibu bapa dipilih dari prasekolah swasta. Daripada saiz sampel bagi bilangan ibu bapa seramai 74 orang dari prasekolah KPM dan prasekolah swasta masing-masing, 37 orang ibu dan 37 orang bapa dipilih sebagai sampel secara rawak.

Dalam kajian ini, soal selidik digunakan bagi melihat tahap kepuasan ibu bapa terhadap kualiti pendidikan prasekolah. Menurut Orodho (2009), soal selidik dianggap paling sesuai kerana keupayaannya untuk mengumpul sejumlah besar maklumat dari sejumlah besar orang dalam tempoh yang singkat. Soal selidik yang digunakan adalah soalan yang telah diubah suai daripada kajian "Keberkesanan pendidikan prasekolah KEMAS dan swasta: perbandingan mengikut persepsi ibu bapa" (Yahaya \& Ramli, 2001) mengikut keperluan pengkaji. Dalam kajian ini, soal selidik terbahagi kepada dua bahagian iaitu bahagian A yang berkaitan dengan maklumat diri responden untuk mendapatkan latar belakang responden dan bahagian B mengandungi 21 item soalan untuk mengukur tahap kepuasan ibu bapa terhadap kualiti pendidikan prasekolah.

Seterusnya, data yang dikumpul dianalisis dengan menggunakan perisian Statistical Package for the Social Science (SPSS) versi 23.0. Kajian ini dikemukakan dalam dua bahagian di mana bahagian pertama iaitu analisis deskriptif yang melaporkan frekuensi, min, sisihan piawai dan peratusan untuk mengenalpasti tahap kepuasan ibu bapa terhadap kualiti pendidikan prasekolah. Tahap kepuasan ibu bapa diukur dengan menjumlahkan skor min responden untuk kesemua 21 item. Nilai min kemudiannya dibandingkan dengan jadual aras bagi memudahkan interpretasi dapatan. Pengkelasan tahap kepuasan ibu bapa ialah dari tahap rendah, sederhana dan tinggi. Jadual aras ini ditentukan dengan membahagikan julat min (1 hingga 4) kepada tiga tahap, iaitu tahap rendah, sederhana dan tinggi.

Jadual 1 : Skala Penentuan Tahap Kepuasan Ibu Bapa

\begin{tabular}{cc}
\hline Pengkelasan Skor Min & Aras \\
\hline $1.00-1.33$ & Rendah \\
$1.34-2.66$ & Sederhana \\
$2.67-4.00$ & Tinggi \\
\hline
\end{tabular}

(Sumber: Asrul Azmin Masiron, 2010)

Seterusnya, bahagian kedua menggunakan statistik inferensi untuk melihat perbezaan tahap kepuasan ibu bapa terhadap kualiti pendidikan prasekolah dari aspek jantina, pendapatan, tahap pendidikan dan jenis prasekolah yang dihadiri oleh anak. Ujian t sampel bebas digunakan untuk menguji sama ada terdapat perbezaan signifikan dalam kepuasan ibu bapa terhadap kualiti pendidikan prasekolah berhubung dengan jantina dan jenis sekolah yang dihadiri oleh anak. Manakala ujian Anova sehala digunakan untuk menguji sama ada terdapat perbezaan dalam kepuasan ibu bapa terhadap kualiti pendidikan prasekolah berhubung dengan tahap pendidikan tertinggi dan pendapatan ibu bapa. 


\section{DAPATAN KAJIAN}

\section{Maklumat Demografi Ibu Bapa}

Maklumat demografi ibu bapa termasuk jantina, jenis prasekolah yang dihadiri oleh anak, tahap pendidikan tertinggi dan pendapatan. Hasil penganalisisan maklumat demografi ibu bapa adalah seperti yang ditunjukkan dalam jadual 2.

Jadual 2: Maklumat Demografi Ibu Bapa

\begin{tabular}{lll}
\hline Kategori demografi & Frekuensi & Peratusan (\%) \\
\hline Jantina & 74 & \\
Lelaki & 74 & $50 \%$ \\
Perempuan & 148 & $50 \%$ \\
Jumlah & 74 & $100 \%$ \\
\hline Jenis Prasekolah Yang Dihadiri Oleh Anak & \\
Prasekolah Kerajaan & 74 & $50 \%$ \\
Prasekolah Swasta & 148 & $50 \%$ \\
Jumlah & & $100 \%$ \\
\hline Tahap Pendidikan Tertinggi & 4 & \\
Sekolah Rendah & 58 & $2.7 \%$ \\
Sekolah Menengah & 50 & $39.2 \%$ \\
Diploma & 34 & $33.8 \%$ \\
Ijazah & 2 & $23.0 \%$ \\
Siswazah Lepasan Ijazah & 148 & $1.4 \%$ \\
Jumlah & & $100 \%$ \\
\hline Pendapatan & 37 & \\
RM1,000 atau kurang & 43 & $25 \%$ \\
RM1,001 - RM2,500 & 61 & $29.1 \%$ \\
RM2,501 - RM5,000 & 7 & $41.2 \%$ \\
RM5,001 dan ke atas & 148 & $4.7 \%$ \\
Jumlah & & $100 \%$ \\
\hline
\end{tabular}

Jadual 2 menunjukkan bahawa daripada 148 orang ibu bapa yang terlibat dalam kajian ini, bilangan responden lelaki yang terlibat ialah seramai 74 orang (50\%) dan responden perempuan ialah seramai 74 orang (50\%). Sementara itu, seramai 74 orang (50\%) ibu bapa mempunyai anak-anak di prasekolah kerajaan dan 74 orang (50\%) ibu bapa mempunyai anak-anak di prasekolah swasta.

Pada peringkat tahap pendidikan tertinggi ibu bapa, jadual menunjukkan bahawa ibu bapa yang memiliki tahap pendidikan sekolah menengah merupakan kumpulan terbesar iaitu seramai 58 orang (39.2\%), diikuti dengan diploma seramai 50 orang (33.8\%), ijazah seramai 34 orang (23\%), sekolah rendah seramai 4 orang (2.7\%) dan ibu bapa yang memiliki tahap pendidikan siswazah lepasan ijazah merupakan kumpulan terkecil iaitu hanya 2 orang (1.4\%).

Berdasarkan jadual juga dapat diketahui bahawa ibu bapa dengan pendapatan bulanan dalam lingkungan RM2,501 - RM5,000 merupakan kumpulan terbesar iaitu seramai 61 orang (41.2\%), diikuti dengan pendapatan bulanan dalam lingkungan RM1,001 - RM2,500 iaitu seramai 43 orang (29.1\%), RM1,000 atau kurang seramai 37 orang (25\%), dan hanya 7 orang (4.7\%) ibu bapa mempunyai pendapatan bulanan dalam lingkungan RM5,001 dan ke atas.

\section{Tahap Kepuasan Ibu Bapa Terhadap Kualiti Pendidikan Prasekolah}

Kajian ini mengkaji tahap kepuasan ibu bapa terhadap kualiti pendidikan prasekolah yang diberikan kepada anak-anak mereka berdasarkan tiga dimensi kualiti pendidikan. Tiga dimensi kualiti pendidikan prasekolah terdiri daripada persekitaran prasekolah, kemudahan dan kelengkapan serta kualiti guru. Untuk mengenal pasti tahap kepuasan ibu bapa, skor min dan sisihan piawai dikira. Semakin besar skor 
min itu, semakin tinggi tahap kepuasan ibu bapa terhadap kualiti pendidikan prasekolah. Hasil ditunjukkan dalam jadual 3.

Jadual 3: Skor Min Tahap Kepuasan Ibu Bapa Terhadap Kualiti Pendidikan Prasekolah

\begin{tabular}{|c|c|c|c|}
\hline Bil & Pernyataan & $\begin{array}{l}\text { Min } \\
(\mathrm{M})\end{array}$ & $\begin{array}{l}\text { Sisihan Piawai } \\
\text { (SP) }\end{array}$ \\
\hline \multicolumn{2}{|c|}{ Persekitaran Prasekolah } & 3.16 & 0.638 \\
\hline 1. & Persekitaran prasekolah sentiasa ceria & 3.24 & 0.694 \\
\hline 2. & $\begin{array}{l}\text { Persekitaran prasekolah selesa dan menggalakkan suasana pengajaran } \\
\text { dan pembelajaran }\end{array}$ & 3.28 & 0.648 \\
\hline 3. & Persekitaran selamat untuk kanak-kanak & 3.34 & 0.603 \\
\hline 4. & $\begin{array}{l}\text { Penyusunan dalam bilik darjah menggalakkan aktiviti pembelajaran } \\
\text { kanak-kanak }\end{array}$ & 3.32 & 0.630 \\
\hline 5. & Pengudaraan dan pengcahayaan yang baik & 2.52 & 0.589 \\
\hline 6. & Kawasan beriadah mencukupi & 3.07 & 0.671 \\
\hline & Jarak prasekolah dari rumah berdekatan & 3.32 & 0.629 \\
\hline \multicolumn{2}{|c|}{ Kemudahan dan Kelengkapan } & 3.07 & 0.662 \\
\hline 8. & Perabot dan peralatan mencukupi dan sesuai dengan keperluan murid & 3.19 & 0.653 \\
\hline 9. & Alat pengajaran dan pembelajaran mencukupi & 3.23 & 0.629 \\
\hline 10. & Peralatan permainan mencukupi & 3.11 & 0.640 \\
\hline 11. & $\begin{array}{l}\text { Peralatan permainan luar sesuai untuk keluasan kawasan yang } \\
\text { disediakan }\end{array}$ & 3.14 & 0.646 \\
\hline 12. & Kemudahan teknologi maklumat yang lengkap & 2.46 & 0.632 \\
\hline 13. & Peti kecemasan yang lengkap & 3.12 & 0.755 \\
\hline 14. & Terdapat pelbagai sudut pembelajaran di dalam bilik darjah & 3.27 & 0.676 \\
\hline \multicolumn{2}{|r|}{ Kualiti Guru } & 3.47 & 0.613 \\
\hline 15. & Tahap pencapaian akademik guru mencukupi & 3.53 & 0.577 \\
\hline 16. & Guru berpengalaman & 3.41 & 0.605 \\
\hline 17. & Guru seorang yang terlatih & 3.43 & 0.651 \\
\hline 18. & Guru seorang yang menepati masa & 3.36 & 0.670 \\
\hline 19. & Guru prihatin dan penyayang & 3.49 & 0.577 \\
\hline 20. & Kaedah kawalan disiplin berkesan & 3.54 & 0.621 \\
\hline & Pemakaian guru sopan & 3.50 & 0.589 \\
\hline \multicolumn{2}{|r|}{ Tahap Kepuasan Keseluruhan Ibu Bapa dengan Kualiti } & $\mathbf{3 . 2 3}$ & 0.638 \\
\hline
\end{tabular}

Hasil daripada analisis berdasarkan jadual 3 menunjukkan bahawa skor min untuk 21 item adalah dari $2.46(\mathrm{SP}=0.632)$ hingga $3.54(\mathrm{SP}=0.621)$. Purata min keseluruhan untuk tahap kepuasan ibu bapa terhadap kualiti pendidikan prasekolah adalah 3.23 ( $\mathrm{SP}=0.638$ ). Ini telah menunjukkan bahawa tahap kepuasan ibu bapa terhadap kualiti pendidikan prasekolah adalah tinggi dan ibu bapa sangat berpuas hati dengan kualiti pendidikan prasekolah.

Seperti yang ditunjukkan dalam jadual 3, ibu bapa sangat berpuas hati dengan dimensi kualiti guru yang mendapat skor min tertinggi iaitu 3.47 ( $\mathrm{SP}=0.613$ ), diikuti dengan dimensi persekitaran prasekolah yang mendapat skor min $3.16(\mathrm{SP}=0.638)$. Sebaliknya, ibu bapa mencapai kepuasan yang rendah dengan dimensi kemudahan dan kelengkapan, di mana ia mendapat skor min yang terendah iaitu 3.07 ( $\mathrm{SP}=0.662$ ). Ini menunjukkan bahawa ibu bapa mempunyai keyakinan yang tinggi terhadap kualiti guru prasekolah berbanding dengan dimensi kualiti pendidikan prasekolah yang lain.

Dalam dimensi kualiti guru, berdasarkan jadual tersebut didapati bahawa pernyataan "kaedah kawalan disiplin berkesan" merupakan paling ketara dengan min $3.54(\mathrm{SP}=0.621)$, diikuti pernyataan "tahap pencapaian akademik guru mencukupi" dengan min 3.53 (SP=0.577). Manakala pernyataan "guru seorang yang menepati masa" mencapai skor min yang terendah iaitu $3.36(\mathrm{SP}=0.670)$. Secara keseluruhan, ibu bapa mempunyai tahap kepuasan yang tinggi terhadap kualiti guru. 
Dalam dimensi persekitaran prasekolah, didapati bahawa pernyataan "persekitaran selamat untuk kanak-kanak" merupakan paling ketara dengan min 3.34 (SP=0.603). Ini menunjukkan bahawa persekitaran prasekolah adalah selamat dan memberi kepuasan yang tinggi kepada ibu bapa. Sebaliknya, pernyataan "pengudaraan dan pengcahayaan yang baik" berada pada tahap kepuasan yang sederhana di mana mencapai skor min yang terendah iaitu $2.52(\mathrm{SP}=0.589)$.

Dalam dimensi kemudahan dan kelengkapan, pernyataan "terdapat pelbagai sudut pembelajaran di dalam bilik darjah" merupakan paling ketara dengan min $3.27(\mathrm{SP}=0.676)$. Ini menunjukkan ibu bapa mempunyai kepuasan yang tinggi dengan kepelbagaian sudut di dalam bilik darjah prasekolah. Manakala pernyataan "kemudahan teknologi maklumat yang lengkap" berada pada tahap kepuasan yang sederhana di mana mencapai skor min yang terendah iaitu 2.46 (SP=0.632). Secara umumnya, dapatan kajian ini menunjukkan bahawa ibu bapa mempunyai tahap kepuasan yang tinggi terhadap kualiti pendidikan prasekolah.

\section{Perbezaan di Antara Tahap Kepuasan Ibu Bapa Terhadap Kualiti Pendidikan Prasekolah Kerajaan dan Swasta}

Untuk mengenal pasti perbezaan di antara tahap kepuasan ibu bapa terhadap kualiti pendidikan prasekolah kerajaan dan swasta, skor min dan sisihan piawai berdasarkan tiga dimensi kualiti (persekitaran prasekolah, kemudahan dan kelengkapan serta kualiti guru) dikira. Hasil kajian ditunjukkan dalam jadual 4.

Jadual 4: Skor Min Tahap Kepuasan Ibu Bapa Terhadap Kualiti Pendidikan Prasekolah Mengikut Jenis Prasekolah

\begin{tabular}{lllll}
\hline Dimensi Kualiti Pendidikan Prasekolah & Jenis Prasekolah & N & Min & SP \\
\hline Persekitaran Prasekolah & Kerajaan & 74 & 2.95 & 0.654 \\
& Swasta & 74 & 3.36 & 0.524 \\
\hline Kemudahan dan Kelengkapan & Kerajaan & 74 & 2.89 & 0.674 \\
& Swasta & 74 & 3.26 & 0.593 \\
\hline Kualiti Guru & Kerajaan & 74 & 3.31 & 0.667 \\
& Swasta & 74 & 3.62 & 0.508 \\
\hline Tahap Kepuasan Keseluruhan Ibu Bapa & Kerajaan & $\mathbf{7 4}$ & $\mathbf{3 . 0 5}$ & $\mathbf{0 . 6 6 5}$ \\
& & & & \\
& Swasta & $\mathbf{7 4}$ & $\mathbf{3 . 4 1}$ & $\mathbf{0 . 5 4 1}$ \\
\hline
\end{tabular}

Hasil daripada analisis berdasarkan jadual 4 menunjukkan bahawa purata min keseluruhan untuk tahap kepuasan ibu bapa terhadap kualiti pendidikan prasekolah dengan mengikut jenis prasekolah adalah 3.05 ( $\mathrm{SP}=0.665$ ) untuk ibu bapa yang anak-anaknya di prasekolah kerajaan dan 3.41 $(\mathrm{SP}=0.541)$ untuk ibu bapa yang anak-anaknya di prasekolah swasta. Dengan ini, dapat disimpulkan bahawa ibu bapa yang anak-anaknya di prasekolah swasta lebih berpuas hati dengan kualiti pendidikan prasekolah daripada ibu bapa yang mempunyai anak-anak di prasekolah kerajaan.

Sementara itu, dapatan kajian menunjukkan bahawa skor min untuk tahap kepuasan ibu bapa terhadap kualiti pendidikan prasekolah adalah lebih tinggi dalam setiap dimensi kualiti pendidikan prasekolah bagi ibu bapa yang mempunyai anak-anaknya di prasekolah swasta berbanding dengan ibu bapa yang anak-anaknya di prasekolah kerajaan. Dalam dimensi persekitaran prasekolah seperti yang ditunjukkan dalam jadual 4, skor min tahap kepuasan ibu bapa yang anak-anaknya di prasekolah kerajaan adalah 2.95 ( $\mathrm{SP}=0.654)$ dan 3.36 ( $\mathrm{SP}=0.524)$ untuk ibu bapa yang mempunyai anak-anak di prasekolah swasta.

Dalam dimensi kemudahan dan kelengkapan, skor min tahap kepuasan ibu bapa yang anakanaknya di prasekolah kerajaan adalah 2.89 ( $\mathrm{SP}=0.674)$ dan $3.26(\mathrm{SP}=0.593)$ bagi ibu bapa yang mempunyai anak-anak di prasekolah swasta. Dalam dimensi kualiti guru pula, skor min tahap kepuasan 
ibu bapa yang anak-anaknya di prasekolah kerajaan adalah 3.31 ( $\mathrm{SP}=0.667)$ dan 3.62 ( $\mathrm{SP}=0.508)$ bagi ibu bapa yang mempunyai anak-anak di prasekolah swasta. Dalam ketiga-tiga dimensi kualiti pendidikan prasekolah ini, dapat dilihat bahawa ibu bapa yang mempunyai anak-anak di prasekolah swasta lebih berpuas hati dengan kualiti pendidikan prasekolah berbanding dengan mereka yang mempunyai anak-anak di prasekolah kerajaan.

Tambahan pula, dapatan kajian menunjukkan skor min yang rendah bagi ibu bapa yang mempunyai anak-anak di kedua-dua jenis prasekolah dalam dimensi kemudahan dan kelengkapan. Ini dapat dilihat skor min adalah 2.89 ( $\mathrm{SP}=0.674)$ untuk ibu bapa di prasekolah kerajaan dan 3.26 $(\mathrm{SP}=0.593)$ untuk ibu bapa di prasekolah swasta.

Sementara itu, hasil kajian juga menunjukkan skor min yang tinggi bagi ibu bapa yang mempunyai anak-anak di kedua-dua jenis prasekolah dalam dimensi kualiti guru. Hal ini dapat ditunjukkan skor min adalah 3.31 ( $\mathrm{SP}=0.667)$ untuk ibu bapa di prasekolah kerajaan dan $3.62(\mathrm{SP}=0.508)$ untuk ibu bapa di prasekolah swasta. Ini menunjukkan bahawa tanpa mengira jenis prasekolah, ibu bapa adalah berpuas hati dengan kualiti guru.

Kajian ini bertujuan untuk mengenal pasti perbezaan di antara tahap kepuasan ibu bapa terhadap kualiti pendidikan prasekolah dengan mengikut jenis prasekolah. Dengan ini, pengkaji menggunakan ujian t sampel bebas untuk menentukan sama ada terdapat perbezaan di antara tahap kepuasan ibu bapa terhadap kualiti pendidikan prasekolah kerajaan dan prasekolah swasta. Hasil kajian ditunjukkan dalam jadual 5 .

Jadual 5: Analisis Ujian t Sampel Bebas Tahap Kepuasan Ibu Bapa Terhadap Kualiti Pendidikan Prasekolah Berdasarkan Jenis Prasekolah

\begin{tabular}{|c|c|c|c|c|c|c|}
\hline $\begin{array}{l}\text { Dimensi Kualiti Pendidikan } \\
\text { Prasekolah }\end{array}$ & Jenis Prasekolah & $\mathrm{N}$ & Min & SP & $\mathrm{t}$ & Sig. \\
\hline \multirow[t]{2}{*}{ Persekitaran Prasekolah } & Kerajaan & 74 & 2.95 & 0.654 & & \\
\hline & Swasta & 74 & 3.36 & 0.524 & 4.209 & 0.001 \\
\hline \multirow[t]{2}{*}{ Kemudahan dan Kelengkapan } & Kerajaan & 74 & 2.89 & 0.674 & & \\
\hline & Swasta & 74 & 3.26 & 0.593 & 3.545 & 0.005 \\
\hline \multirow[t]{2}{*}{ Kualiti Guru } & Kerajaan & 74 & 3.31 & 0.667 & & \\
\hline & Swasta & 74 & 3.62 & 0.508 & 3.181 & 0.018 \\
\hline \multirow{2}{*}{$\begin{array}{l}\text { Tahap Kepuasan Keseluruhan } \\
\text { Ibu Bapa }\end{array}$} & Kerajaan & 74 & 3.05 & $\overline{0.665}$ & & \\
\hline & Swasta & 74 & 3.41 & 0.541 & 3.613 & 0.004 \\
\hline
\end{tabular}

* signifikan pada $\mathrm{p}<0.05$

Analisis ujian t sampel bebas pada jadual 5 menunjukkan bahawa terdapat perbezaan yang signifikan di antara tahap kepuasan ibu bapa terhadap kualiti pendidikan prasekolah kerajaan dan prasekolah swasta $(\mathrm{t}=3.613, \mathrm{df}=146, \mathrm{p}=0.004)$. Sementara itu, dapatan kajian juga menunjukkan bahawa terdapat perbezaan yang signifikan $(\mathrm{p}<0.05)$ dengan tahap kepuasan di antara ibu bapa terhadap pendidikan prasekolah kerajaan dan prasekolah swasta dalam ketiga-tiga dimensi kualiti pendidikan prasekolah. Oleh itu, dapat disimpulkan bahawa ibu bapa di prasekolah swasta lebih berpuas hati terhadap kualiti pendidikan prasekolah berbanding dengan ibu bapa di prasekolah kerajaan dan terdapat perbezaan yang signifikan.

\section{Perbezaan di Antara Tahap Kepuasan Ibu Bapa Terhadap Kualiti Pendidikan Prasekolah dengan Faktor Jantina}

Untuk mengenal pasti perbezaan di antara tahap kepuasan ibu bapa terhadap kualiti pendidikan prasekolah dengan faktor jantina, skor min dan sisihan piawai berdasarkan tiga dimensi kualiti 
(persekitaran prasekolah, kemudahan dan kelengkapan serta kualiti guru) dikira. Hasil kajian ditunjukkan dalam jadual 6.

Jadual 6: Skor Min Tahap Kepuasan Ibu Bapa Terhadap Kualiti Pendidikan Prasekolah Mengikut Faktor Jantina

\begin{tabular}{lllll}
\hline Dimensi Kualiti Pendidikan Prasekolah & Jantina & N & Min & SP \\
\hline Persekitaran Prasekolah & Lelaki & 74 & 3.19 & 0.634 \\
& Perempuan & 74 & 3.12 & 0.639 \\
\hline Kemudahan dan Kelengkapan & Lelaki & 74 & 3.14 & 0.636 \\
& Perempuan & 74 & 3.00 & 0.681 \\
\hline Kualiti Guru & Lelaki & 74 & 3.52 & 0.606 \\
& Perempuan & 74 & 3.41 & 0.618 \\
\hline Tahap Kepuasan Keseluruhan Ibu Bapa & Lelaki & $\mathbf{7 4}$ & $\mathbf{3 . 2 8}$ & $\mathbf{0 . 6 2 5}$ \\
dengan Kualiti & Perempuan & $\mathbf{7 4}$ & $\mathbf{3 . 1 8}$ & $\mathbf{0 . 6 4 6}$ \\
\hline
\end{tabular}

Hasil daripada analisis berdasarkan jadual 6 menunjukkan bahawa purata min keseluruhan untuk tahap kepuasan ibu bapa terhadap kualiti pendidikan prasekolah dengan mengikut faktor jantina adalah 3.28 ( $\mathrm{SP}=0.625)$ untuk bapa dan $3.18(\mathrm{SP}=0.646)$ untuk ibu. Dengan ini, dapat disimpulkan bahawa bapa lebih berpuas hati terhadap kualiti pendidikan prasekolah berbanding dengan ibu.

Sementara itu, dapatan kajian menunjukkan bahawa skor min untuk tahap kepuasan ibu bapa terhadap kualiti pendidikan prasekolah adalah lebih tinggi dalam setiap dimensi kualiti pendidikan prasekolah bagi bapa berbanding dengan ibu. Dalam dimensi persekitaran prasekolah, skor min tahap kepuasan bapa adalah 3.19 ( $\mathrm{SP}=0.634)$ dan $3.12(\mathrm{SP}=0.639)$ untuk ibu. Dalam dimensi kemudahan dan kelengkapan, skor min tahap kepuasan bapa adalah $3.14(\mathrm{SP}=0.636)$ dan $3.00(\mathrm{SP}=0.681)$ untuk ibu. Dalam dimensi kualiti guru pula, skor min tahap kepuasan bapa adalah $3.52(\mathrm{SP}=0.606)$ dan 3.41 $(\mathrm{SP}=0.618)$ untuk ibu. Dalam ketiga-tiga dimensi kualiti pendidikan prasekolah ini, dapat dilihat bahawa bapa lebih berpuas hati terhadap kualiti pendidikan prasekolah berbanding dengan ibu.

Tambahan pula, dapatan kajian menunjukkan skor min yang rendah bagi kedua-dua ibu bapa dalam dimensi kemudahan dan kelengkapan. Ini dapat dilihat skor min adalah $3.14(\mathrm{SP}=0.636)$ untuk bapa dan 3.00 ( $\mathrm{SP}=0.681$ ) untuk ibu. Sementara itu, hasil kajian juga menunjukkan skor min yang tinggi bagi kedua-dua ibu bapa dalam dimensi kualiti guru. Hal ini dapat ditunjukkan skor min adalah 3.52 $(\mathrm{SP}=0.606)$ untuk bapa dan 3.41 ( $\mathrm{SP}=0.618)$ untuk ibu. Ini menunjukkan bahawa tanpa mengira faktor jantina, ibu bapa adalah berpuas hati dengan kualiti guru.

Kajian ini bertujuan untuk mengenal pasti perbezaan di antara tahap kepuasan ibu bapa terhadap kualiti pendidikan prasekolah dengan mengikut faktor jantina. Dengan ini, pengkaji menggunakan ujian t sampel bebas untuk menentukan sama ada terdapat perbezaan di antara tahap kepuasan ibu bapa terhadap kualiti pendidikan prasekolah dengan berdasarkan faktor jantina. Hasil kajian ditunjukkan dalam jadual 7.

Jadual 7: Analisis Ujian t Sampel Bebas Tahap Kepuasan Ibu Bapa Terhadap Kualiti Pendidikan Prasekolah Berdasarkan Faktor Jantina

\begin{tabular}{lllllll}
\hline Dimensi Kualiti Pendidikan Prasekolah & Jantina & N & Min & SP & t & Sig. \\
\hline Persekitaran Prasekolah & Lelaki & 74 & 3.19 & 0.634 & & \\
& Perempuan & 74 & 3.12 & 0.639 & 0.669 & 0.505 \\
\hline Kemudahan dan Kelengkapan & Lelaki & 74 & 3.14 & 0.636 & & \\
& Perempuan & 74 & 3.00 & 0.681 & 1.293 & 0.198 \\
\hline Kualiti Guru & Lelaki & 74 & 3.52 & 0.606 & & \\
& Perempuan & 74 & 3.41 & 0.618 & 1.093 & 0.276 \\
\hline
\end{tabular}




\begin{tabular}{lllllll}
\hline Tahap Kepuasan Keseluruhan Ibu Bapa & Lelaki & 74 & 3.28 & 0.625 & & 0.340 \\
& Perempuan & 74 & 3.18 & 0.646 & 0.957 & 0.340 \\
\hline
\end{tabular}

* signifikan pada $\mathrm{p}<0.05$

Analisis ujian t sampel bebas pada jadual 7 menunjukkan bahawa tidak ada perbezaan yang signifikan di antara tahap kepuasan ibu bapa terhadap kualiti pendidikan prasekolah berdasarkan faktor jantina ( $\mathrm{t}=0.957, \mathrm{df}=146, \mathrm{p}=0.340$ ). Ini bermakna ibu bapa adalah berpuas hati terhadap kualiti pendidikan prasekolah tanpa mengira jantina mereka.

Sementara itu, dapatan kajian ini juga menunjukkan bahawa tidak ada perbezaan yang signifikan $(\mathrm{p}<0.05)$ dengan tahap kepuasan di antara ibu bapa terhadap pendidikan prasekolah berdasarkan faktor jantina dalam ketiga-tiga dimensi kualiti pendidikan prasekolah. Oleh yang demikian, dapat disimpulkan bahawa ibu bapa prasekolah mempunyai tahap kepuasan yang sama terhadap kualiti pendidikan prasekolah tanpa mengira jantina mereka dan tidak ada perbezaan yang signifikan.

\section{Perbezaan di Antara Tahap Kepuasan Ibu Bapa Terhadap Kualiti Pendidikan Prasekolah dengan Faktor Tahap Pendidikan}

Untuk mengenal pasti perbezaan di antara tahap kepuasan ibu bapa terhadap kualiti pendidikan prasekolah dengan faktor tahap pendidikan, skor min dan sisihan piawai berdasarkan tiga dimensi kualiti (persekitaran prasekolah, kemudahan dan kelengkapan serta kualiti guru) dikira. Hasil kajian telah ditunjukkan dalam jadual 8.

Jadual 8: Skor Min Tahap Kepuasan Ibu Bapa Terhadap Kualiti Pendidikan Prasekolah Mengikut Faktor Tahap Pendidikan

\begin{tabular}{llll}
\hline Dimensi Kualiti Pendidikan Prasekolah & N & Min & SP \\
\hline Persekitaran Prasekolah & $\mathbf{1 4 8}$ & $\mathbf{3 . 2 6}$ & $\mathbf{0 . 5 0 8}$ \\
Sekolah Rendah & 4 & 3.21 & 0.490 \\
Sekolah Menengah & 58 & 3.09 & 0.664 \\
Diploma & 50 & 3.08 & 0.623 \\
Ijazah & 34 & 3.35 & 0.562 \\
Siswazah Lepasan Ijazah & 2 & 3.57 & 0.202 \\
\hline Kemudahan dan Kelengkapan & $\mathbf{1 4 8}$ & $\mathbf{3 . 2 0}$ & $\mathbf{0 . 4 9 4}$ \\
Sekolah Rendah & 4 & 3.07 & 0.308 \\
Sekolah Menengah & 58 & 3.04 & 0.685 \\
Diploma & 50 & 2.99 & 0.675 \\
Ijazah & 34 & 3.21 & 0.598 \\
Siswazah Lepasan Ijazah & 2 & 3.71 & 0.202 \\
\hline Kualiti Guru & $\mathbf{1 4 8}$ & $\mathbf{3 . 6 4}$ & $\mathbf{0 . 4 0 3}$ \\
Sekolah Rendah & 4 & 3.79 & 0.214 \\
Sekolah Menengah & 58 & 3.36 & 0.642 \\
Diploma & 50 & 3.45 & 0.623 \\
Ijazah & 34 & 3.59 & 0.536 \\
Siswazah Lepasan Ijazah & 2 & 4.00 & 0.000 \\
\hline Tahap Kepuasan Keseluruhan Ibu Bapa & $\mathbf{1 4 8}$ & $\mathbf{3 . 3 7}$ & $\mathbf{0 . 4 6 8}$ \\
Sekolah Rendah & 4 & 3.36 & 0.337 \\
Sekolah Menengah & 58 & 3.16 & 0.664 \\
Diploma & 50 & 3.17 & 0.640 \\
Ijazah & 34 & 3.38 & 0.565 \\
Siswazah Lepasan Ijazah & 2 & 3.76 & 0.135 \\
\hline
\end{tabular}

Hasil kajian berdasarkan jadual 8 menunjukkan bahawa skor min keseluruhan kepuasan ibu bapa dengan siswazah lepasan ijazah adalah yang tertinggi iaitu 3.76 ( $\mathrm{SP}=0.135)$, diikuti dengan ijazah 
yang mempunyai skor min 3.38 ( $\mathrm{SP}=0.565)$, sijil sekolah rendah dengan skor min 3.36 ( $\mathrm{SP}=0.337)$, sijil diploma dengan skor min 3.17 ( $\mathrm{SP}=0.640$ ) dan sijil sekolah menengah dengan skor min 3.16 ( $\mathrm{SP}=0.664)$. Hasil kajian ini menunjukkan bahawa ibu bapa dengan tahap pendidikan yang lebih tinggi adalah lebih berpuas hati terhadap kualiti pendidikan prasekolah berbanding dengan ibu bapa yang mempunyai tahap pendidikan yang rendah.

Sementara itu, hasil kajian menunjukkan bahawa ibu bapa dengan siswazah lepasan ijazah mempunyai skor min yang tertinggi dalam setiap dimensi kualiti pendidikan prasekolah. Tambahan pula, ibu bapa dengan semua peringkat pendidikan menunjukkan skor min tertinggi pada dimensi kualiti guru.

Berdasarkan objektif kajian, kajian ini bertujuan untuk mengenal pasti perbezaan di antara tahap kepuasan ibu bapa terhadap kualiti pendidikan prasekolah dengan mengikut faktor tahap pendidikan. Dengan ini, pengkaji menggunakan Analisis Varians (ANOVA) sehala untuk menentukan sama ada terdapat perbezaan di antara tahap kepuasan ibu bapa terhadap kualiti pendidikan prasekolah dengan berdasarkan faktor tahap pendidikan. Jadual 9 menunjukkan keputusan ANOVA sehala.

Jadual 9: Analisis Ujian ANOVA Sehala Tahap Kepuasan Ibu Bapa Terhadap Kualiti Pendidikan Prasekolah Berdasarkan Faktor Tahap Pendidikan

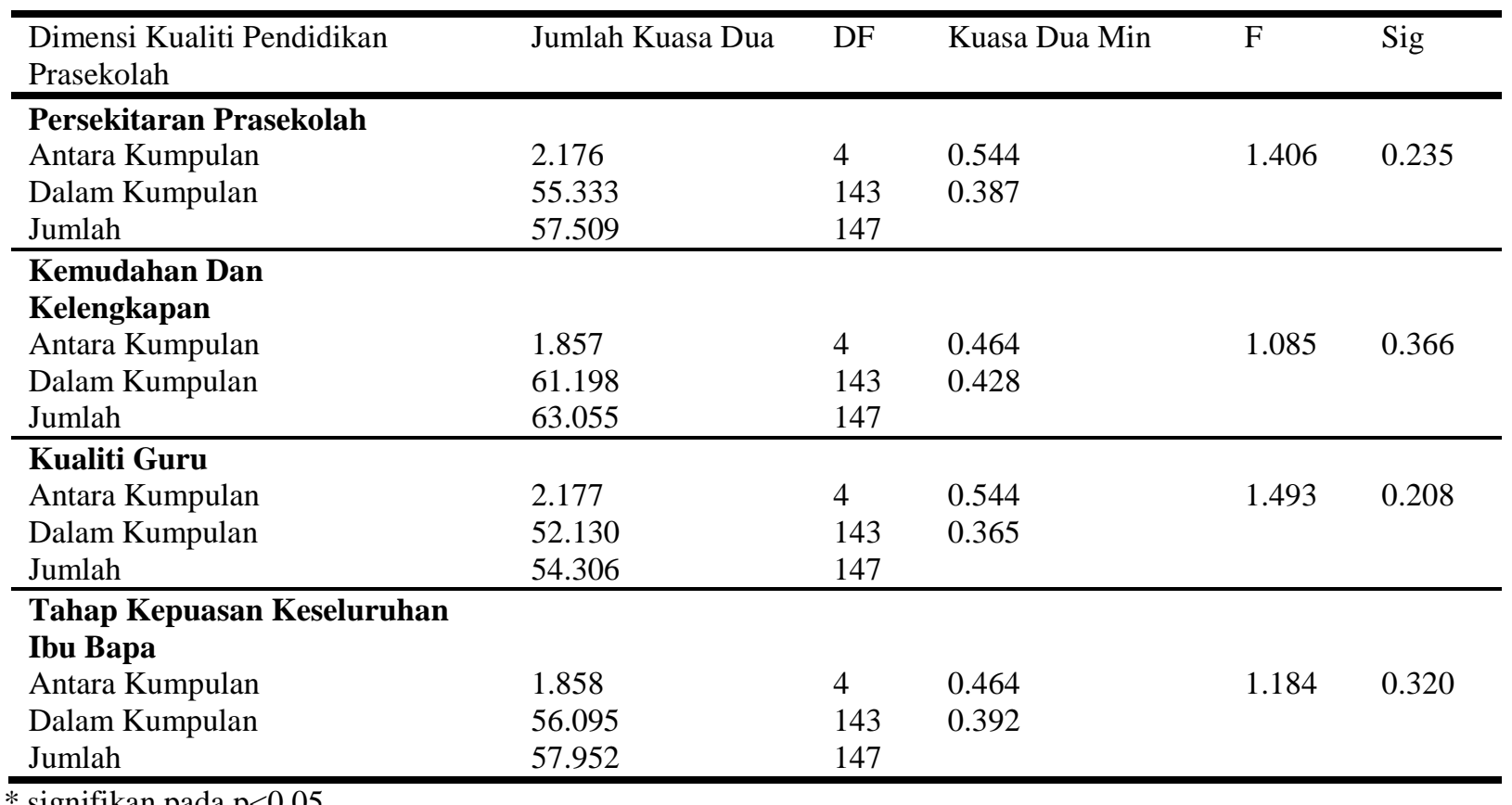

* signifikan pada $\mathrm{p}<0.05$

Analisis ujian ANOVA sehala berdasarkan jadual 9 menunjukkan bahawa tidak terdapat perbezaan yang signifikan di antara tahap kepuasan ibu bapa terhadap kualiti pendidikan prasekolah berdasarkan faktor tahap pendidikan, iaitu $\mathrm{F}(4,143)=1.184, \mathrm{p}=0.320$. Oleh itu, hasil kajian menunjukkan bahawa ibu bapa dari tahap pendidikan yang berbeza mempunyai tahap kepuasan yang sama terhadap kualiti pendidikan prasekolah.

Di samping itu, hasil kajian ini juga menunjukkan bahawa tidak ada perbezaan yang signifikan $(\mathrm{p}<0.05)$ dengan tahap kepuasan antara ibu bapa terhadap pendidikan prasekolah berdasarkan faktor tahap pendidikan dalam dimensi persekitaran prasekolah $(\mathrm{F}[4,143]=1.406, \mathrm{p}=0.235)$, kemudahan dan kelengkapan $(\mathrm{F}[4,143]=1.085, \mathrm{p}=0.366)$, dan kualiti guru $(\mathrm{F}[4,143]=1.493, \mathrm{p}=0.208)$. Oleh yang demikian, dapat disimpulkan bahawa ibu bapa prasekolah mempunyai tahap kepuasan yang sama terhadap kualiti pendidikan prasekolah tanpa mengira tahap pendidikan mereka dan tidak ada perbezaan yang signifikan. 


\section{Perbezaan di Antara Tahap Kepuasan Ibu Bapa Terhadap Kualiti Pendidikan Prasekolah dengan Faktor Pendapatan}

Untuk mengenal pasti perbezaan di antara tahap kepuasan ibu bapa terhadap kualiti pendidikan prasekolah dengan faktor pendapatan, skor min dan sisihan piawai berdasarkan tiga dimensi kualiti, iaitu persekitaran prasekolah, kemudahan dan kelengkapan serta kualiti guru telah dikira. Hasil kajian telah ditunjukkan dalam jadual 10.

Jadual 10: Skor Min Tahap Kepuasan Ibu Bapa Terhadap Kualiti Pendidikan Prasekolah Mengikut Faktor Pendapatan

\begin{tabular}{llll}
\hline Dimensi Kualiti Pendidikan Prasekolah & N & Min & SP \\
\hline Persekitaran Prasekolah & $\mathbf{1 4 8}$ & $\mathbf{3 . 1 6}$ & $\mathbf{0 . 6 2 3}$ \\
RM1,000 atau kurang & 37 & 3.17 & 0.681 \\
RM1,001 - RM2,500 & 43 & 3.03 & 0.650 \\
RM2,501 - RM5,000 & 61 & 3.24 & 0.593 \\
RM5,001 dan ke atas & 7 & 3.20 & 0.566 \\
\hline Kemudahan dan Kelengkapan & $\mathbf{1 4 8}$ & $\mathbf{3 . 0 6}$ & $\mathbf{0 . 6 6 3}$ \\
RM1,000 atau kurang & 37 & 3.09 & 0.776 \\
RM1,001 - RM2,500 & 43 & 2.94 & 0.642 \\
RM2,501 - RM5,000 & 61 & 3.16 & 0.585 \\
RM5,001 dan ke atas & 7 & 3.06 & 0.648 \\
\hline Kualiti Guru & $\mathbf{1 4 8}$ & $\mathbf{3 . 4 3}$ & $\mathbf{0 . 6 2 3}$ \\
RM1,000 atau kurang & 37 & 3.37 & 0.677 \\
RM1,001 - RM2,500 & 43 & 3.39 & 0.656 \\
RM2,501 - RM5,000 & 61 & 3.59 & 0.507 \\
RM5,001 dan ke atas & 7 & 3.37 & 0.650 \\
\hline Tahap Kepuasan Keseluruhan Ibu Bapa & $\mathbf{1 4 8}$ & $\mathbf{3 . 2 2}$ & $\mathbf{0 . 6 3 6}$ \\
RM1,000 atau kurang & 37 & 3.21 & 0.711 \\
RM1,001 - RM2,500 & 43 & 3.12 & 0.649 \\
RM2,501 - RM5,000 & 61 & 3.33 & 0.562 \\
RM5,001 dan ke atas & 7 & 3.21 & 0.621 \\
\hline
\end{tabular}

Hasil kajian berdasarkan jadual 10 menunjukkan bahawa skor min keseluruhan kepuasan ibu bapa dengan pendapatan RM2,501 - RM5,000 adalah yang tertinggi iaitu 3.33 ( $\mathrm{SP}=0.562$ ), diikuti dengan pendapatan RM5,001 dan ke atas yang mempunyai skor min $3.21(\mathrm{SP}=0.621)$ serta pendapatan $\mathrm{RM} 1,000$ atau kurang dengan skor min 3.21 ( $\mathrm{SP}=0.711)$. Manakala skor min keseluruhan kepuasan ibu bapa dengan pendapatan RM1,001 - RM2,500 adalah yang terendah iaitu 3.12 ( $\mathrm{SP}=0.649)$. Oleh itu, daripada analisis berdasarkan jadual 4.9, dapat disimpulkan bahawa ibu bapa dengan pendapatan RM2,501 - RM5,000 adalah lebih berpuas hati terhadap kualiti pendidikan prasekolah berbanding dengan ibu bapa yang mempunyai tahap pendapatan yang lain.

Sementara itu, hasil kajian menunjukkan bahawa ibu bapa dengan pendapatan RM2,501 RM5,000 mempunyai skor min yang tertinggi dalam setiap dimensi kualiti pendidikan prasekolah. Tambahan pula, ibu bapa dengan semua tahap pendapatan menunjukkan skor min tertinggi pada dimensi kualiti guru.

Berdasarkan objektif kajian, kajian ini bertujuan untuk mengenal pasti perbezaan di antara tahap kepuasan ibu bapa terhadap kualiti pendidikan prasekolah dengan mengikut faktor tahap pendidikan. Dengan ini, pengkaji menggunakan Analisis Varians (ANOVA) sehala untuk menentukan sama ada terdapat perbezaan di antara tahap kepuasan ibu bapa terhadap kualiti pendidikan prasekolah dengan berdasarkan faktor tahap pendidikan. Jadual 11 menunjukkan keputusan ANOVA sehala. 
Jadual 11: Analisis Ujian ANOVA Sehala Tahap Kepuasan Ibu Bapa Terhadap Kualiti Pendidikan Prasekolah Berdasarkan Faktor Pendapatan

\begin{tabular}{|c|c|c|c|c|c|}
\hline $\begin{array}{l}\text { Dimensi Kualiti Pendidikan } \\
\text { Prasekolah }\end{array}$ & Jumlah Kuasa Dua & $\mathrm{DF}$ & Kuasa Dua Min & $\mathrm{F}$ & Sig \\
\hline $\begin{array}{l}\text { Persekitaran Prasekolah } \\
\text { Antara Kumpulan } \\
\text { Dalam Kumpulan } \\
\text { Jumlah } \\
\end{array}$ & $\begin{array}{l}1.132 \\
57.461 \\
58.593 \\
\end{array}$ & $\begin{array}{l}3 \\
144 \\
147 \\
\end{array}$ & $\begin{array}{l}0.377 \\
0.399\end{array}$ & 0.946 & 0.420 \\
\hline $\begin{array}{l}\text { Kemudahan Dan } \\
\text { Kelengkapan } \\
\text { Antara Kumpulan } \\
\text { Dalam Kumpulan } \\
\text { Jumlah } \\
\end{array}$ & $\begin{array}{l}1.234 \\
62.042 \\
63.276 \\
\end{array}$ & $\begin{array}{l}3 \\
144 \\
147 \\
\end{array}$ & $\begin{array}{l}0.411 \\
0.431\end{array}$ & 0.955 & 0.416 \\
\hline $\begin{array}{l}\text { Kualiti Guru } \\
\text { Antara Kumpulan } \\
\text { Dalam Kumpulan } \\
\text { Jumlah } \\
\end{array}$ & $\begin{array}{l}1.592 \\
52.532 \\
54.124 \\
\end{array}$ & $\begin{array}{l}3 \\
144 \\
147 \\
\end{array}$ & $\begin{array}{l}0.531 \\
0.365\end{array}$ & 1.454 & 0.230 \\
\hline $\begin{array}{l}\text { Tahap Kepuasan Keseluru } \\
\text { Ibu Bapa } \\
\text { Antara Kumpulan } \\
\text { Dalam Kumpulan } \\
\text { Jumlah }\end{array}$ & $\begin{array}{l}1.146 \\
57.154 \\
58.300 \\
\end{array}$ & $\begin{array}{l}3 \\
144 \\
147\end{array}$ & $\begin{array}{l}0.382 \\
0.397\end{array}$ & 0.963 & 0.412 \\
\hline
\end{tabular}

* signifikan pada $\mathrm{p}<0.05$

Analisis ujian ANOVA sehala berdasarkan jadual 11 menunjukkan bahawa tidak terdapat perbezaan yang signifikan di antara tahap kepuasan ibu bapa terhadap kualiti pendidikan prasekolah berdasarkan faktor pendapatan, iaitu $\mathrm{F}(3,144)=0.963$, $\mathrm{p}=0.412$. Oleh itu, hasil kajian menunjukkan bahawa ibu bapa yang mempunyai tahap pendapatan yang berbeza mempunyai tahap kepuasan yang sama terhadap kualiti pendidikan prasekolah.

Di samping itu, hasil kajian ini juga menunjukkan bahawa tidak ada perbezaan yang signifikan $(\mathrm{p}<0.05)$ dengan tahap kepuasan antara ibu bapa terhadap pendidikan prasekolah berdasarkan faktor pendapatan dalam dimensi persekitaran prasekolah $(\mathrm{F}[3,144]=0.946, \mathrm{p}=0.420)$, kemudahan dan kelengkapan $(\mathrm{F}[3,144]=0.955, \mathrm{p}=0.416)$, dan kualiti guru $(\mathrm{F}[3,144]=1.454, \mathrm{p}=0.230)$. Oleh yang demikian, dapat disimpulkan bahawa ibu bapa prasekolah mempunyai tahap kepuasan yang sama terhadap kualiti pendidikan prasekolah tanpa mengira tahap pendapatan mereka dan tidak ada perbezaan yang signifikan.

\section{PERBINCANGAN}

Hasil kajian menunjukkan bahawa kebanyakan ibu bapa mempunyai tahap kepuasan yang tinggi terhadap kualiti pendidikan prasekolah. Hal ini dapat ditunjukkan bahawa pada skala Likert empat mata, skor purata tahap kepuasan ibu bapa terhadap kualiti pendidikan prasekolah adalah 3.23 ( $\mathrm{SP}=0.638$ ). Ini bermakna kebanyakan ibu bapa prasekolah di daerah Maran, Pahang mempunyai keyakinan yang tinggi terhadap kualiti pendidikan prasekolah yang diberikan kepada anak-anak mereka.

Seperti yang ditunjukkan dalam dapatan kajian, dalam ketiga-tiga dimensi kualiti pendidikan prasekolah, iaitu dimensi persekitaran prasekolah, dimensi kemudahan dan kelengkapan serta dimensi kualiti guru, ibu bapa mencapai tahap kepuasan yang rendah dengan dimensi kemudahan dan kelengkapan yang mendapat skor min 3.07 ( $\mathrm{SP}=0.662$ ). Ibu bapa kurang berpuas hati dengan kemudahan teknologi maklumat yang dianggap kurang lengkap dan perlu ditambahbaik lagi. Kekurangan teknologi maklumat yang lengkap merupakan faktor penting kepada guru-guru yang 
memerlukan peralatan tersebut untuk mengajar. Apabila menghadapi kekurangan kemudahan teknologi maklumat ini, ianya mungkin akan menjejaskan kualiti pengajaran guru.

Sebaliknya, ibu bapa sangat berpuas hati dengan dimensi kualiti guru yang mendapat skor min tertinggi iaitu 3.47 ( $\mathrm{SP}=0.613)$. Ibu bapa berpuas hati dengan kaedah kawalan disiplin guru yang berkesan, tahap pencapaian akademik guru mencukupi dan juga pemakaian guru yang sopan. Ini menunjukkan bahawa walaupun ibu bapa mencapai tahap kepuasan yang lebih rendah dengan dimensi kualiti pendidikan prasekolah yang lain, mereka mempunyai keyakinan dan kepercayaan yang tinggi terhadap guru anak-anak mereka.

Sementara itu, dapatan kajian menunjukkan bahawa terdapat perbezaan yang signifikan di antara tahap kepuasan ibu bapa terhadap kualiti pendidikan prasekolah kerajaan dan prasekolah swasta $(\mathrm{t}=3.613, \mathrm{df}=146, \mathrm{p}=0.004)$. Ibu bapa yang anak-anaknya di prasekolah swasta $(\mathrm{M}=3.41, \mathrm{SP}=0.541)$ lebih berpuas hati terhadap kualiti pendidikan prasekolah berbanding dengan ibu bapa yang anakanaknya di prasekolah kerajaan $(\mathrm{M}=3.05, \mathrm{SP}=0.665)$. Ini menunjukkan bahawa tahap kepuasan ibu bapa terhadap kualiti pendidikan prasekolah bergantung kepada jenis prasekolah dari segi kerajaan atau swasta. Dapatan kajian juga menunjukkan bahawa ibu bapa dalam kedua-dua jenis prasekolah ini berpuas hati dengan kualiti guru dan mempunyai kepercayaan yang tinggi terhadap kualiti guru. Penemuan kajian ini bersesuaian dengan Charles (2011) yang membandingkan persepsi ibu bapa terhadap kualiti sekolah di antara sekolah rendah kerajaan dan swasta di Amerika Syarikat. Charles mendapati bahawa persepsi tentang kualiti sekolah dalam kalangan ibu bapa yang anak-anaknya di sekolah swasta jauh lebih tinggi daripada ibu bapa yang anak-anaknya di sekolah kerajaan.

Seterusnya, dapatan kajian menunjukkan bahawa tidak terdapat perbezaan yang signifikan di antara tahap kepuasan ibu bapa terhadap kualiti pendidikan prasekolah dengan berdasarkan faktor jantina $(\mathrm{t}=0.957, \mathrm{df}=146, \mathrm{p}=0.340)$. Dapatan kajian ini bersesuaian dengan Qiu (2004) yang menunjukkan bahawa jantina ibu bapa tidak terdapat perbezaan signifikan yang mempengaruhi ibu bapa untuk membuat keputusan di prasekolah.

Selain itu, tidak terdapat perbezaan yang signifikan di antara tahap kepuasan ibu bapa terhadap kualiti pendidikan prasekolah dengan berdasarkan faktor tahap pendidikan $(F[4,143]=1.184, p=0.320)$. Dapatan kajian ini bertepatan dengan Al Jabery, et al. (2014) yang menyatakan bahawa tidak terdapat perbezaan yang signifikan dalam kepuasan ibu bapa dengan perkhidmatan pendidikan yang disediakan pada pelbagai tahap pendidikan.

Akhir sekali, dapatan kajian juga menunjukkan tidak terdapat perbezaan yang signifikan di antara tahap kepuasan ibu bapa terhadap kualiti pendidikan prasekolah dengan berdasarkan faktor pendapatan ibu bapa $(\mathrm{F}[3,144]=0.963, \mathrm{p}=0.412)$. Ini bermakna jantina, tahap pendidikan dan pendapatan ibu bapa tidak mempunyai pengaruh yang signifikan terhadap tahap kepuasan ibu bapa dengan kualiti pendidikan prasekolah yang diberikan kepada anak-anak mereka.

\section{CADANGAN}

Berdasarkan dapatan kajian ini, beberapa cadangan telah dibuat untuk pelbagai pihak berkepentingan dan untuk penyelidikan selanjutnya. Cadangan itu amat penting bagi pihak yang berwajib untuk meningkatkan lagi kualiti pendidikan prasekolah. Beberapa cadangan dinyatakan seperti berikut:

\section{Cadangan dasar}

a) Kerajaan perlu memantau secara berterusan kualiti pendidikan prasekolah yang disediakan di daerah dan memastikan prasekolah tersebut memenuhi piawaian kualiti perkhidmatan pendidikan prasekolah. Proses pemantauan hendaklah meliputi kepuasan ibu bapa terhadap kualiti perkhidmatan pendidikan prasekolah yang ditawarkan. Dengan ini, maklumat daripada soal selidik tentang 
kepuasan ibu bapa terhadap kualiti pendidikan prasekolah harus digunakan untuk merancang dan melaksanakan program yang bertujuan untuk mengekalkan penyediaan perkhidmatan pendidikan yang berkualiti. Sementara itu, kerajaan perlu memperuntukkan lebih banyak dana untuk program pendidikan prasekolah dan meningkatkan infrastruktur di prasekolah.

b) Pembuat dasar Kementerian Pendidikan disyorkan untuk membangunkan kenyataan dasar yang kukuh yang disokong oleh komitmen kewangan untuk memastikan keadaan prasarana, kemudahan dan kelengkapan di prasekolah bertambah baik. Dengan menambahbaikan prasarana, kemudahan dan kelengkapan di prasekolah, ia dapat meningkatkan dan menggalakkan aktiviti pengajaran dan pembelajaran di prasekolah.

c) Kajian menunjukkan kebanyakan ibu bapa prasekolah di daerah Maran, Pahang mempunyai keyakinan terhadap kualiti guru. Dengan ini, pengetua prasekolah tidak boleh memandang ringan terhadap perkara ini kerana kualiti pendidikan yang diberikan kepada kanak-kanak adalah bergantung kepada sebahagian besar kelayakan guru, pengalaman dan komitmen guru, minat dalam kalangan kanak-kanak serta keluarga mereka. Bagi mengekalkan ibu bapa untuk terus mempercayai dan mempunyai keyakinan yang tinggi terhadap kualiti guru prasekolah, guru-guru perlu diberi motivasi dengan menyokong mereka untuk melanjutkan pelajaran. Sementara itu, guru perlu bermotivasi dengan ditaja untuk menghadiri latihan dalam perkhidmatan (seminar dan bengkel) untuk memulihkan dan meningkatkan pengetahuan mereka. Hal ini bukan sahaja memberi manfaat kepada guru tetapi juga kepada kanak-kanak, ibu bapa dan juga prasekolah. Dengan menghadiri latihan dalam perkhidmatan, guru-guru dapat berkongsi maklumat dan sumber baru dengan rakan sekerja, menawarkan perkhidmatan yang berkualiti kepada kanak-kanak dan keluarga mereka. Dengan ini, ibu bapa akan berpuas hati dan mengekalkan anak-anak mereka di prasekolah tersebut. Di samping itu, pengetua prasekolah perlu memperuntukkan sumber dengan sewajarnya untuk memastikan aspek struktur prasekolah ditingkatkan ke tahap yang diperlukan. Pengetua prasekolah harus memastikan kawasan beriadah, bahan pengajaran dan pembelajaran disediakan untuk aktiviti pengajaran dan pembelajaran yang berkesan.

d) Ibu bapa harus terlibat secara aktif dengan menyertai Persatuan Ibu Bapa dan Guru bagi menyuarakan pandangan mereka dalam menyediakan pendidikan prasekolah yang berkualiti kepada kanak-kanak. Ibu bapa akan menyuarakan pandangan mereka tentang jenis perkhidmatan pendidikan yang mereka harapkan dari prasekolah supaya didengar dan dipertimbangkan. Walau bagaimanapun, ibu bapa harus berhati-hati semasa menyuarakan pandangan dengan tidak meletakkan tekanan yang tidak perlu kepada guru-guru prasekolah.

\section{Cadangan untuk penyelidikan lanjutan}

a) Kajian ini hanya terhad kepada daerah Maran, Pahang sahaja. Oleh itu, disyorkan bahawa kajian serupa ini yang merangkumi sebahagian besar kawasan di Pahang dapat dilakukan untuk memberikan gambaran yang lebih luas tentang kepuasan ibu bapa terhadap kualiti pendidikan prasekolah.

b) Kajian ini melaporkan perspektif ibu bapa berkenaan dengan kepuasan terhadap kualiti pendidikan prasekolah. Kajian serupa dapat direplikasi dalam kalangan guru untuk menentukan tahap kepuasan guru prasekolah terhadap kualiti pendidikan prasekolah.

c) Kajian ini memberi tumpuan kepada tahap kepuasan ibu bapa terhadap kualiti pendidikan prasekolah dari perspektif ibu bapa. Oleh sebab kajian serupa jarang didokumenkan dari perspektif kanak-kanak berkenaan dengan kualiti pendidikan prasekolah yang diterima oleh mereka, oleh yang demikian adalah perlu untuk melakukan penyelidikan dan mengumpulkan pendapat mereka. Hal ini disebabkan kanak-kanak merupakan sumber maklumat yang terbaik mengenai isu-isu yang berkaitan dengan mereka. 
d) Kajian ini memberi tumpuan dalam mengenal pasti perbezaan di antara tahap kepuasan ibu bapa terhadap kualiti pendidikan prasekolah dengan berdasarkan faktor jenis prasekolah, jantina, tahap pendidikan dan pendapatan. Mungkin terdapat faktor-faktor lain yang mempengaruhi tahap kepuasan ibu bapa terhadap kualiti pendidikan prasekolah seperti perbezaan budaya, lokasi, status perkahwinan, umur dan pekerjaan. Oleh itu, kajian serupa mungkin boleh mengenal pasti tahap kepuasan ibu bapa dengan berdasarkan faktor-faktor ini.

\section{KESIMPULAN}

Kesimpulan daripada kajian ini menunjukkan bahawa ibu bapa sangat berpuas hati dengan kualiti pendidikan prasekolah yang diberikan kepada anak-anak mereka di daerah Maran, Pahang dengan skor min keseluruhan 3.23 pada skala Likert 4 mata. Dalam setiap dimensi kualiti pendidikan prasekolah, dapatan kajian menunjukkan bahawa ibu bapa sangat berpuas hati dengan dimensi kualiti guru. Sementara itu, ibu bapa kurang berpuas hati dengan kemudahan dan kelengkapan prasekolah. Seterusnya, terdapat perbezaan yang signifikan di antara tahap kepuasan ibu bapa terhadap kualiti pendidikan prasekolah kerajaan dan prasekolah swasta. Walau bagaimanapun, kajian ini menunjukkan bahawa tidak terdapat perbezaan yang signifikan di antara tahap kepuasan ibu bapa terhadap kualiti pendidikan prasekolah dengan faktor jantina, tahap pendidikan dan pendapatan ibu bapa.

\section{RUJUKAN}

Al Jabery, M., Arabiat, D., Al Khamra, H., Betawi, I., \& Jabbar, S. (2014). Parental perceptions of services provided for children with autism in Jordan. Journal of Child and Family Studies, 23(3), 475-486.

Al Shatti, H. (2011). Parents' perspectives of government \& private kindergarten systems in Kuwait. Newcastle University.

Azizi Yahaya \& Jamaludin Ramli (2001). Keberkesanan pendidikan prasekolah KEMAS dan swasta: Perbandingan mengikut persepsi ibu bapa. Universiti Teknologi Malaysia.

Charles, G. W. (2011). Parental perceptions of school quality ingGovernment and private schools. Northcentral University, ProQuest Dissertations Publishing.

Chua, Y.P. (2014). Kaedah penyelidikan. (Edisi Ketiga). Shah Alam: McGraw-Hill Education.

Da Silva, L., \& Wise, S. (2006). Parent perspectives on childcare service quality among a culturally diverse sample. Australian Journal of Early Childhood, 31(3), 6-14.

Fraenkel, J.R., \& Wallen, N.E. (2009). How to design and evaluate research in education (7th Ed.). Boston: McGraw Hill Higher Education.

Goldring, E. \& Rowley, K. J. (2006). Parent preferences and parent choices: The public-private decision about school choice. National Research And Development Center on School Choice.

Kementerian Pendidikan Malaysia. (2017). Sistem Maklumat Prasekolah Kebangsaan. Bahagian Pengurusan Maklumat.

Krejcie, R.V., \& Morgan, D.W. (1970). Determining sample size for research activities. Educational and Psychological Measurement, 30, 608.

Mbise, A. S. (2008). Early childhood service delivery mapping and baseline study in Bagamoyo, Hai, Magu and Mtwara: Summary of findings and recommendations. Dar es Salaam: Ministry of Education and Vocational Training.

Noor Azlan Ahmad Zanzali \& Mohd Nazri Hamid. (2010). Kesediaan guru program pengijazahan perguruan $(P K P G)$ UTM terhadap mengajar mata pelajaran Sains dan Matematik dalam Bahasa Inggeris. Universiti Teknologi Malaysia.

Norhamiza Ismail. (2009). Faktor-faktor yang mempengaruhi ibu bapa menghantar anak ke prasekolah KEMAS di parlimen Gelang Patah Johor. Universiti Teknologi Malaysia.

Norsalmiah Muhammad. (2009). Faktor-faktor yang mempengaruhi ibu bapa menghantar anak-anak mereka ke prasekolah swasta di daerah Skudai, Johor Bahru. Universiti Teknologi Malaysia.

Omondi, A. M. (2013). Parental satisfaction with the quality of pre-primary education in Bondo District, Siaya County, Kenya. Unpublished M. Ed Thesis, Kenyatta University.

Orodho, J. A. (2009). Elements of education and social science research methods. (2nd ed.). Maseno-Kenya: Kanezia Publisher. 
Qiu, H. F. (2004). The Study of Parental Consumer Decision Making Behavior of Kindergarten in Taipei and Kaohsiung. Unpublished Master's Thesis, National Ping-Tung University of Science and Technology, PingTung, Taiwan.

Sander, S. (2003). Why quality physical activity programs are important. Department of Health and Physical Education at Tennessee Technological University, Washington, DC.

Shabnam, N. (2003). Pre-school education and under-privileged children. New Delhi: Sarup. 